\title{
Thermodynamic Property Study of Nanostructured Mg-H, Mg-Ni-H, and Mg-Cu-H Systems by High Pressure DSC Method
}

\author{
Huaiyu Shao, ${ }^{1}$ Gongbiao Xin, ${ }^{2}$ Xingguo $\mathrm{Li}^{2}$ and Etsuo Akiba ${ }^{1}$ \\ ${ }^{1}$ International Institute for Carbon-Neutral Energy Research (WPI- I2CNER), Kyushu University, Fukuoka 819-0395, Japan \\ ${ }^{2}$ Beijing National Laboratory for Molecular Sciences (BNLMS), and The State Key Laboratory of Rare Earth Materials Chemistry and \\ Applications, College of Chemistry and Molecular Engineering, Peking University, Beijing 100871, China
}

Correspondence should be addressed to Huaiyu Shao; h.shao@i2cner.kyushu-u.ac.jp and Xingguo Li; xgli@pku.edu.cn

Received 13 December 2012; Accepted 17 January 2013

Academic Editor: Jianxin Zou

Copyright (c) 2013 Huaiyu Shao et al. This is an open access article distributed under the Creative Commons Attribution License, which permits unrestricted use, distribution, and reproduction in any medium, provided the original work is properly cited.

\begin{abstract}
$\mathrm{Mg}, \mathrm{Ni}$, and $\mathrm{Cu}$ nanoparticles were synthesized by hydrogen plasma metal reaction method. Preparation of $\mathrm{Mg}_{2} \mathrm{Ni}_{\text {and }} \mathrm{Mg} \mathrm{Cu} \mathrm{Cu}$ alloys from these $\mathrm{Mg}, \mathrm{Ni}$, and $\mathrm{Cu}$ nanoparticles has been successfully achieved in convenient conditions. High pressure differential scanning calorimetry (DSC) technique in hydrogen atmosphere was applied to study the synthesis and thermodynamic properties of the hydrogen absorption/desorption processes of nanostructured $\mathrm{Mg}-\mathrm{H}, \mathrm{Mg}-\mathrm{Ni}-\mathrm{H}$, and $\mathrm{Mg}-\mathrm{Cu}-\mathrm{H}$ systems. Van't Hoff equation of $\mathrm{Mg}-\mathrm{Ni}-\mathrm{H}$ system as well as formation enthalpy and entropy of $\mathrm{Mg}_{2} \mathrm{NiH}_{4}$ was obtained by high pressure DSC method. The results agree with the ones by pressure-composition isotherm (PCT) methods in our previous work and the ones in literature.
\end{abstract}

\section{Introduction}

$\mathrm{Mg}$ and $\mathrm{Mg}$-based alloys are widely studied as hydrogen storage materials for the advantages such as low price, light weight, high hydrogen capacity, and high abundance of $\mathrm{Mg}$ in the earth's crust [1-4]. The hydrides of $\mathrm{Mg}$ and the common Mg-based alloys show considerable hydrogen storage content-7.6 mass\% for $\mathrm{MgH}_{2}$ and 3.6, 4.5, and 5.4 mass\% for $\mathrm{Mg}_{2} \mathrm{NiH}_{4}, \mathrm{Mg}_{2} \mathrm{CoH}_{5}$, and $\mathrm{Mg}_{2} \mathrm{FeH}_{6}$, respectively. Recently some new hydrogen storage materials have been explored [4, 5], but Mg-based materials are still ones of the most promising hydrogen storage candidates to many researchers, especially for heat storage or stationary energy storage $[3,6]$, in which cases, working temperature can be above $500 \mathrm{~K}$.

One serious barrier of Mg-based alloys for hydrogen storage study is synthesis of these alloys by conventional melting method because of the large difference in melting point and vaporization pressure between $\mathrm{Mg}$ and $\mathrm{Ni}, \mathrm{Co}$, $\mathrm{Fe}$, and so forth. Ball milling/mechanical alloying method has been developed to synthesize Mg-based alloys and it is considered as one effective way to prepare nonequilibrium alloy samples with plenty of defects and samples with grain size in nanometer scale [7]. Recently it has almost become the main preparation method by many groups to study $\mathrm{Mg}$-based alloys [8-20]. However, this method faces the disadvantage of possible pollution by steel balls or air during the milling process. Another difficulty in the study of $\mathrm{Mg}$-based materials is poor kinetics of these materials. For example, $\mathrm{Mg}_{2} \mathrm{Ni}$ in micrometer scale produced by conventional melting method needs absorption/desorption temperature higher than $500 \mathrm{~K}$ even after several hydrogen absorption and desorption cycles under hydrogen pressure atmosphere. Common $\mathrm{Mg}$ metal samples in micrometer scale need much stricter conditions to absorb and desorb hydrogen. Our group and some other researchers successfully prepared nanostructured Mgbased alloy and hydride samples in convenient conditions from metal nanoparticles which were synthesized by plasma metal reaction [21-26]. These nanostructured samples show excellent hydrogen storage kinetics and properties. They can absorb and desorb hydrogen in convenient conditions without any activation process $[23,27,28]$. This work is to demonstrate that we can study the preparation process, thermodynamic properties, and reaction mechanism of 
these nanostructured Mg-based materials by high pressure differential scanning calorimetry (DSC) technique under hydrogen atmosphere.

\section{Experimental Details}

The $\mathrm{Mg}, \mathrm{Ni}$, and $\mathrm{Cu}$ nanoparticles were synthesized from bulk metals by hydrogen plasma metal reaction method. Bulk $\mathrm{Mg}, \mathrm{Ni}$, and $\mathrm{Cu}$ metals (purity > 99.7\%) were melted and vaporized by hydrogen-plasma-metal reaction in the chamber and the gaseous metals were taken to the collecting room by the circulating gas and were deposited on the filter wall, where we obtained the $\mathrm{Mg}, \mathrm{Ni}$, and $\mathrm{Cu}$ metal nanoparticles. To prepare $\mathrm{Mg}-\mathrm{Ni}$ and $\mathrm{Mg}-\mathrm{Cu}$ system alloys and hydrides, $\mathrm{Mg}$ and $\mathrm{Ni}(\mathrm{Cu})$ nanoparticles were weighted at a 2:1 molar ratio and mixed in acetone by an ultrasonic homogenizer. Then the mixture was dried and pressed into small pieces, from which, $\mathrm{Mg}-\mathrm{Ni}(\mathrm{Mg}-\mathrm{Cu})$ hydrides were synthesized in $4 \mathrm{MPa}$ hydrogen atmosphere at $623 \mathrm{~K}(673 \mathrm{~K})$ for $2 \mathrm{~h}(9 \mathrm{~h})$ and alloys were obtained after the evacuation of the hydrides at the same temperature.

The composition and structure analysis of the samples were carried out by X-ray diffraction at an automatic Rigaku $\mathrm{X}$-ray diffractometer with monochromatic $\mathrm{Cu} \mathrm{K} \alpha$ radiation at a scanning rate of $4^{\circ} / \mathrm{min}$.

The synthesis and thermodynamic properties of $\mathrm{Mg}-\mathrm{H}$, $\mathrm{Mg}-\mathrm{Ni}-\mathrm{H}$, and $\mathrm{Mg}-\mathrm{Cu}-\mathrm{H}$ systems were studied from DSC measurements using a NETZSCH DSC 204 HP apparatus starting from metal nanoparticles. $\mathrm{Mg}, 2 \mathrm{Mg}+\mathrm{Ni}$ and $2 \mathrm{Mg}+\mathrm{Cu}$ nanoparticle mixture samples with about $10 \mathrm{mg}$ in weight were put into the chamber of the DSC apparatus. After closure of the system, evacuation and supply of $0.5 \mathrm{MPa}$ hydrogen cycles were conducted to fresh the system. For the synthesis of $\mathrm{Mg}-\mathrm{Ni}-\mathrm{H}$ and $\mathrm{Mg}-\mathrm{Cu}-\mathrm{H}$ system, a flowing and constant hydrogen atmosphere of $4 \mathrm{MPa}$ pressure was provided to the DSC chamber system. A special device is equipped in this DSC machine to keep the flowing atmosphere constant. The temperature was increased from room temperature to $823 \mathrm{~K}$ at a heating rate of $20 \mathrm{~K} / \mathrm{min}$. The heating and cooling processes were repeated two more cycles after the first synthesis cycle. After the production of $\mathrm{Mg}_{2} \mathrm{NiH}_{4}$, the sample was taken through several heating and cooling cycles between $453 \mathrm{~K}$ and $823 \mathrm{~K}$ at 5, 10, and $20 \mathrm{~K} / \mathrm{min}$ in various flowing and constant hydrogen pressure value $(1 \mathrm{MPa}, 2 \mathrm{MPa}$, and $4 \mathrm{MPa})$.

\section{Results and Discussion}

Figures 1 and 2 show the XRD curves of the metal nanoparticle samples by hydrogen plasma metal reaction method and $\mathrm{Mg}-\mathrm{Ni}-\mathrm{H}, \mathrm{Mg}-\mathrm{Cu}-\mathrm{H}$ system samples prepared from these metal nanoparticles. Figure 1(a) shows the metal nanoparticle sample prepared from bulk Mg contains pure $\mathrm{Mg}$ phase. $\mathrm{Mg}$ nanoparticle sample shows hexagonal structure and the space group is $\mathrm{P}_{3} / \mathrm{mmc}$. The size is in the range of a few hundred $\mathrm{nm}$. There is a small reflection peak at $42.9^{\circ}$, which is due to the small amount of $\mathrm{MgO}$ impurity (less than 1 mass\%). All of the other peaks are indexed to $\mathrm{Mg}$ phase. This thin layer $\mathrm{MgO}$ actually is very helpful to prevent the $\mathrm{Mg}$ particles

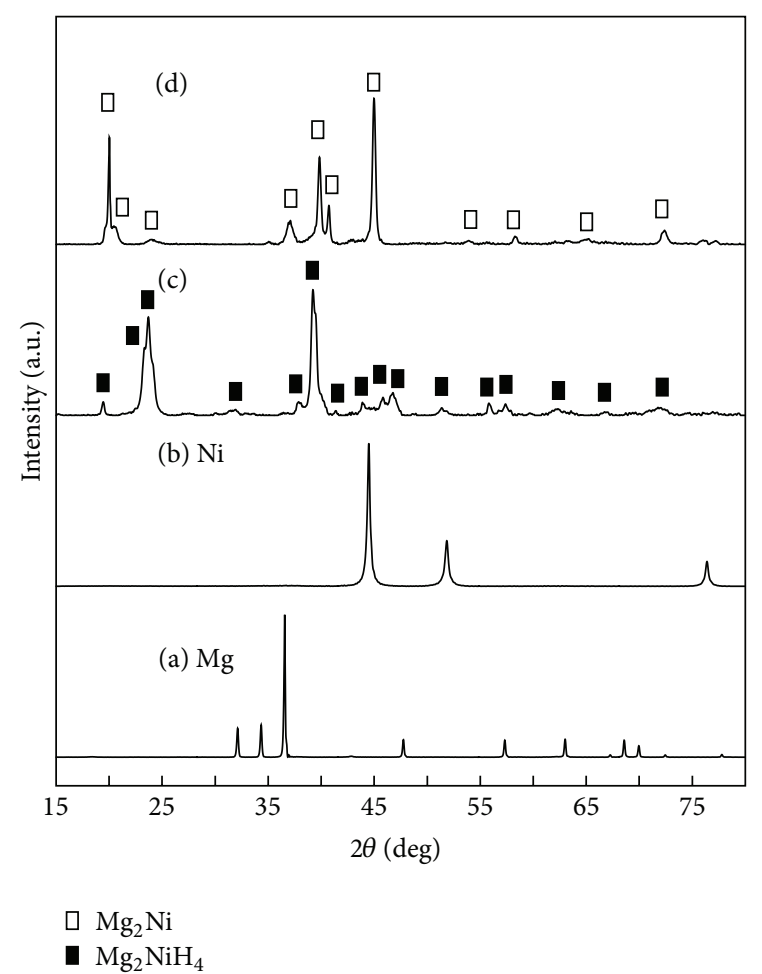

FIGURE 1: XRD patterns of (a) Mg nanoparticles, (b) Ni nanoparticles, (c) $\mathrm{Mg}_{2} \mathrm{NiH}_{4}$ sample prepared from $\mathrm{Mg}$ and $\mathrm{Ni}$ nanoparticles at $623 \mathrm{~K}$ in $4 \mathrm{MPa}$ hydrogen for 2 hours, and (d) $\mathrm{Mg}_{2} \mathrm{Ni}$ sample prepared after evacuation of $\mathrm{Mg}_{2} \mathrm{NiH}_{4}$.

from further oxidation. The reflection peaks in Figure 1(b) are all ascribed to $\mathrm{Ni}$ nanoparticles. Ni sample shows facecentered cubic structure of Fm $3 \mathrm{~m}$ space group. The broadening of Ni peaks indicates the nanostructure of Ni samples. The particle size is about $30-50 \mathrm{~nm}$. Figure 1 (c) presents the $\mathrm{Mg}_{2} \mathrm{NiH}_{4}$ sample prepared from $2 \mathrm{Mg}+\mathrm{Ni}$ nanoparticle mixture by sintering in $4 \mathrm{MPa}$ hydrogen at $623 \mathrm{~K}$ for $2 \mathrm{~h}$. The XRD curve is well indexed to monoclinic $\mathrm{Mg}_{2} \mathrm{NiH}_{4}$ lowtemperature phase (space group: $\mathrm{C} 2 / \mathrm{m}$ ). After evacuation of the $\mathrm{Mg}_{2} \mathrm{NiH}_{4}$ sample, $\mathrm{Mg}_{2} \mathrm{Ni}$ alloy (hexagonal structure, space group: $\mathrm{P}_{2} 22$ ) was obtained (Figure $1(\mathrm{~d})$ ). Hydrogen and nanostructure of the metal samples play important roles in the preparation of $\mathrm{Mg}_{2} \mathrm{NiH}_{4}$ and $\mathrm{Mg}_{2} \mathrm{Ni}$ samples in convenient conditions.

Figure 2(b) indicates XRD curve of the obtained $\mathrm{Cu}$ nanoparticles. Only $\mathrm{Cu}$ phase is observed, which is facecentered cubic structure with the space group of Fm $3 \mathrm{~m}$. The $\mathrm{Cu}$ peaks are also broad because of the nanostructure of the $\mathrm{Cu}$ phase. From $2 \mathrm{Mg}+\mathrm{Cu}$ nanoparticle mixture, firstly $\mathrm{Mg}-$ $\mathrm{Cu}-\mathrm{H}$ hydride sample was obtained by sintering the mixture sample in $4 \mathrm{MPa}$ hydrogen atmosphere at $673 \mathrm{~K}$ for $9 \mathrm{~h}$ and the XRD curve of the obtained hydrides sample is shown in Figure 2(c). The sample mainly consists of $\mathrm{MgH}_{2}$ (tetragonal structure, space group: $\mathrm{P}_{2} / \mathrm{mnm}$ ) and $\mathrm{MgCu}_{2}$ (face-centered cubic structure, space group: $\mathrm{Fd} 3 \mathrm{~m}$ ) phases. For $\mathrm{Mg}-\mathrm{Cu}-\mathrm{H}$ system, there is no ternary hydride found in literature up to now. After the evacuation, $\mathrm{Mg}_{2} \mathrm{Cu}$ main phase sample 


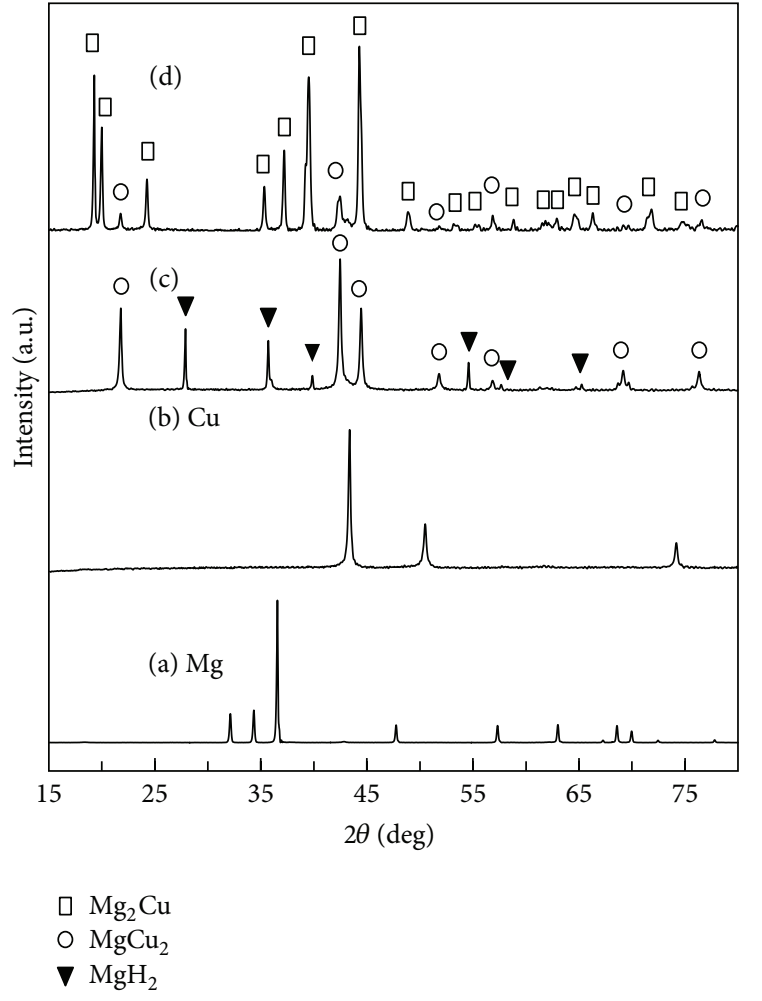

FIGURE 2: XRD patterns of (a) Mg nanoparticles, (b) Cu nanoparticles, (c) $\mathrm{Mg}-\mathrm{Cu}-\mathrm{H}$ hydride sample prepared from $\mathrm{Mg}$ and $\mathrm{Cu}$ nanoparticles at $673 \mathrm{~K}$ in $4 \mathrm{MPa}$ hydrogen for 9 hours, and (d) $\mathrm{Mg}_{2} \mathrm{Cu}$ sample prepared after evacuation of $\mathrm{Mg}-\mathrm{Cu}-\mathrm{H}$ hydride system.

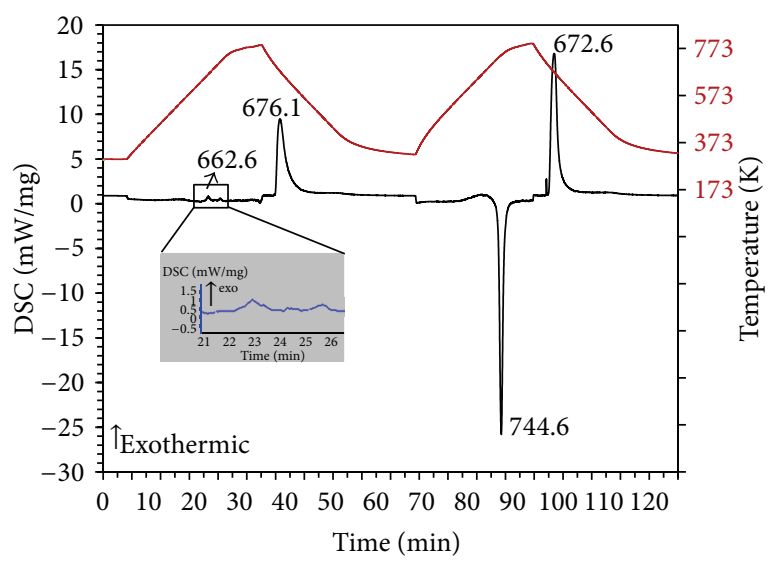

Figure 3: DSC curve of Mg-H system started from $\mathrm{Mg}$ nanoparticle sample in $4 \mathrm{MPa}$ hydrogen pressure.

(orthorhombic, space group: Fddd) was obtained. A small amount of $\mathrm{MgCu}_{2}$ impurity is detected.

Figure 3 shows the DSC curve of the Mg nanoparticles in an initial hydrogen pressure of $4 \mathrm{MPa}$, at a scan rate of $20 \mathrm{~K} / \mathrm{min}$. The upper dash line indicates the temperature trend and the solid line shows the DSC curve. The first peak is a small exothermic peak at $662.6 \mathrm{~K}$, which is due to the

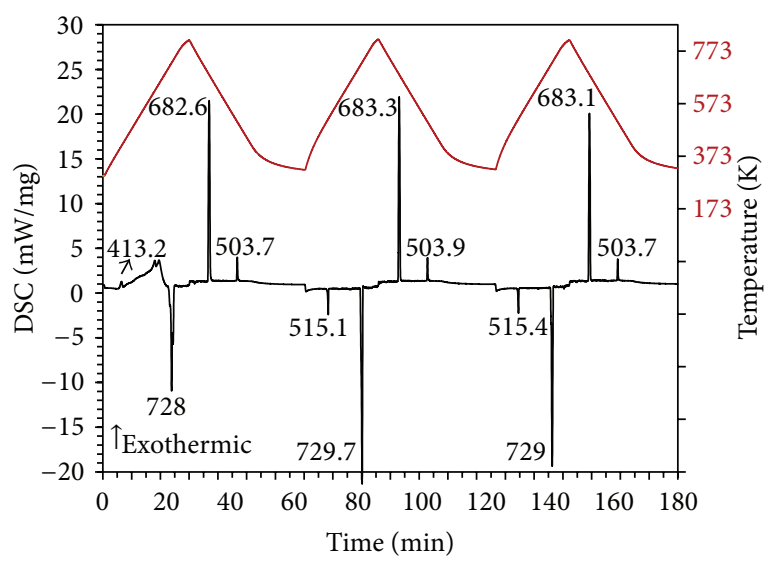

Figure 4: DSC curve of $\mathrm{Mg}-\mathrm{Ni}-\mathrm{H}$ system started from $2 \mathrm{Mg}+\mathrm{Ni}$ nanoparticle mixture in $4 \mathrm{MPa}$ hydrogen pressure.

hydrogen absorption of small amount of $\mathrm{Mg}$ nanoparticles. Most of the $\mathrm{Mg}$ begins to react with hydrogen to form $\mathrm{MgH}_{2}$ in the first cooling cycle and shows an exothermic peak at $676.1 \mathrm{~K}$. Firstly, only partial Mg sample reacts with hydrogen to form the hydride because at the beginning of the hydrogen absorption, it is difficult for hydrogen to penetrate the $\mathrm{MgO}$ layer on the surface of $\mathrm{Mg}$ nanoparticles and then enter the interior of $\mathrm{Mg}$ particles in very short time with heating rate of $20 \mathrm{~K} / \mathrm{min}$ due to kinetic limitation. After the $\mathrm{Mg}$ particle surface are cracked by the entry of hydrogen, much more fresh surface occurs and makes it easier for hydrogen to enter the $\mathrm{Mg}$ particle interior and react with the left $\mathrm{Mg}$ to form $\mathrm{MgH}_{2}$. The reaction equations are expressed as follows:

$$
\begin{aligned}
& \mathrm{Mg}+\mathrm{H}_{2} \longrightarrow \mathrm{MgH}_{2}, \\
& \mathrm{MgH}_{2} \longrightarrow \mathrm{Mg}+\mathrm{H}_{2} .
\end{aligned}
$$

In the second heating cycle, the hydrogenated $\mathrm{MgH}_{2}$ desorbs hydrogen to form $\mathrm{Mg}$ phase and shows an endothermic peak with a peak temperature of $744.6 \mathrm{~K}$ (2). The formed $\mathrm{Mg}$ absorbs hydrogen again during the second cooling process and shows a peak temperature of $672.6 \mathrm{~K}$ (1).

Figure 4 presents the DSC result of starting sample$2 \mathrm{Mg}+\mathrm{Ni}$ nanoparticle mixture in $4 \mathrm{MPa}$ hydrogen, at a scan rate of $20 \mathrm{~K} / \mathrm{min}$. The first exothermic peak at $413.2 \mathrm{~K}$ is attributed to the hydrogen absorption of part of the $\mathrm{Mg}$ nanoparticles (1) with Ni as catalyst. The hydrogen absorption peak of $\mathrm{Mg}$ nanoparticles is about $250 \mathrm{~K}$ lowered (compared to Figure 3) when there are Ni nanoparticles as catalyst, which indicates the excellent catalytic effect of $\mathrm{Ni}$ nanoparticles to the hydrogen absorption of $\mathrm{Mg}$ phase. At about 430 $450 \mathrm{~K}$, there are several exothermic peaks, which are also due to hydrogen absorption of the rest $\mathrm{Mg}$ nanoparticles. The formed $\mathrm{MgH}_{2}$ reacts with $\mathrm{Ni}$ to form $\mathrm{Mg}_{2} \mathrm{Ni}$ and shows an endothermic peak in the first heating period at $728.0 \mathrm{~K}$. The reaction is expressed as follows:

$$
\mathrm{MgH}_{2}+\mathrm{Ni} \longrightarrow \mathrm{Mg}_{2} \mathrm{Ni}+\mathrm{H}_{2} .
$$

The $\mathrm{Mg}_{2}$ Ni phase absorbs hydrogen and shows an exothermic peak at $682.6 \mathrm{~K}$ in the first cooling cycle, which is ascribed to 


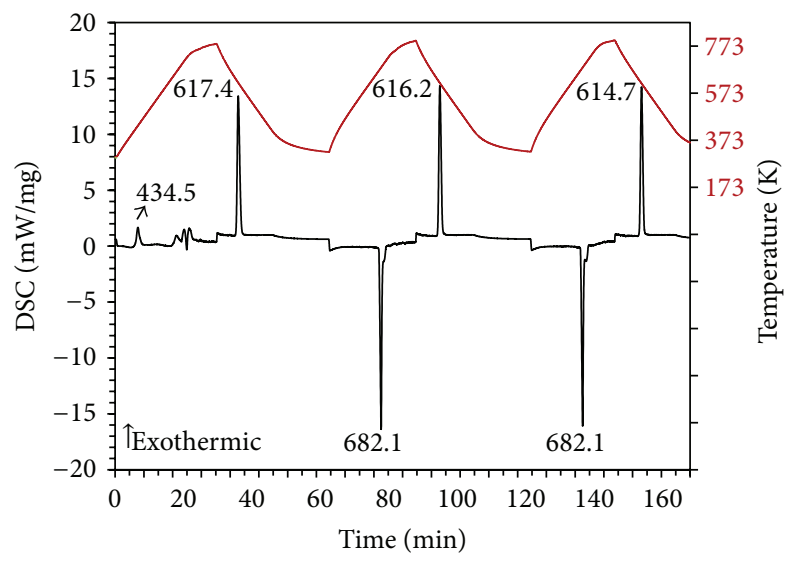

Figure 5: DSC curve of $\mathrm{Mg}-\mathrm{Cu}-\mathrm{H}$ system started from $2 \mathrm{Mg}+\mathrm{Cu}$ nanoparticle mixture in $4 \mathrm{MPa}$ hydrogen pressure.

(4). The exothermic peaks at $683.3 \mathrm{~K}$ in the second cooling cycle and $683.1 \mathrm{~K}$ in the third cycle have the same attribution:

$$
\mathrm{Mg}_{2} \mathrm{Ni}+\mathrm{H}_{2} \longrightarrow \mathrm{Mg}_{2} \mathrm{NiH}_{4}
$$

A small exothermic peak at $503.7 \mathrm{~K}$ in the first cooling cycle is due to the transformation of high temperature (HT) $\mathrm{Mg}_{2} \mathrm{NiH}_{4}$ phase to low temperature one (LT) (5). The exothermic peak at $503.9 \mathrm{~K}$ in the second cooling cycle and the one at $503.7 \mathrm{~K}$ in the third cooling cycle are due to the same transformation reaction. The exothermic peak at $515.1 \mathrm{~K}$ in the second heating cycle and the one at $515.4 \mathrm{~K}$ at the third heating cycle are due to the transformation of low temperature $\mathrm{Mg}_{2} \mathrm{NiH}_{4}$ phase to high temperature one as follows:

$$
\mathrm{Mg}_{2} \mathrm{NiH}_{4}(\mathrm{HT}) \longleftrightarrow \mathrm{Mg}_{2} \mathrm{NiH}_{4}(\mathrm{LT})
$$

The high and sharp peak at $729.7 \mathrm{~K}$ at the second heating cycle and the one at $729.0 \mathrm{~K}$ at the third cycle are due to desorption of $\mathrm{Mg}_{2} \mathrm{NiH}_{4}$ phase to form $\mathrm{Mg}_{2} \mathrm{Ni}$ and hydrogen as follows:

$$
\mathrm{Mg}_{2} \mathrm{NiH}_{4} \longrightarrow \mathrm{Mg}_{2} \mathrm{Ni}+\mathrm{H}_{2}
$$

Figure 5 indicates the DSC curve of $2 \mathrm{Mg}+\mathrm{Cu}$ nanoparticle mixture in $4 \mathrm{MPa}$ hydrogen atmosphere. The heating and cooling rate is $20 \mathrm{~K} / \mathrm{min}$. The first exothermic peak occurs at $434.5 \mathrm{~K}$, which is corresponding to the hydrogen absorption of $\mathrm{Mg}$ nanoparticles with $\mathrm{Cu}$ nanoparticles as the catalyst. This is similar to $\mathrm{Mg}-\mathrm{Ni}-\mathrm{H}$ system in Figure 4. With $\mathrm{Cu}$ catalyst, the hydrogenation peak temperature is lowered about $230 \mathrm{~K}$. After the first exothermic peak, there are several exothermic and endothermic peaks in the temperature range of $660 \mathrm{~K}$ to $740 \mathrm{~K}$ in the first heating period. The attribution of these peaks remains unclear currently. After these peaks, the next peak at $617.4 \mathrm{~K}$ in the first cooling cycle could be easily defined as hydrogen absorption peak of $\mathrm{Mg}_{2} \mathrm{Cu}$ phase according to DSC results of $\mathrm{Mg}-\mathrm{H}$ system in Figure 3 and pressure-composition isotherm (PCT) results reported by us before [28]. The reactions of (1), (7), and (8) are thought to

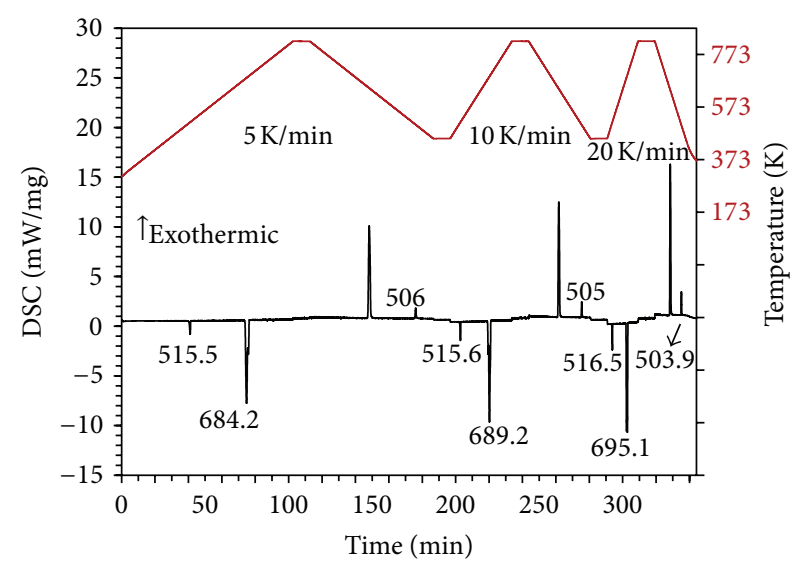

Figure 6: DSC curve of Mg-Ni-H system in $2 \mathrm{MPa}$ hydrogen, at different scan rates started from $\mathrm{Mg}_{2} \mathrm{NiH}_{4}$ sample.

contribute to these peaks between $600 \mathrm{~K}$ and $740 \mathrm{~K}$ in the first heating process as follows:

$$
\begin{gathered}
\mathrm{MgH}_{2}+\mathrm{Cu} \longrightarrow \mathrm{Mg}_{2} \mathrm{Cu}+\mathrm{H}_{2}, \\
\mathrm{Mg}+\mathrm{Cu} \longrightarrow \mathrm{Mg}_{2} \mathrm{Cu} .
\end{gathered}
$$

The sharp exothermic peaks at $617.4 \mathrm{~K}, 616.2 \mathrm{~K}$, and $614.7 \mathrm{~K}$ in the cooling period are due to the hydrogen absorption of $\mathrm{Mg}_{2} \mathrm{Cu}$ expressed as (9), which could be easily confirmed by the XRD results after the DSC measurement. The large sharp endothermic peaks at $682.1 \mathrm{~K}$ in the second and third cycles are attributed to desorption of $\mathrm{MgH}_{2}$ and $\mathrm{MgCu}_{2}$ mixture to form $\mathrm{Mg}_{2} \mathrm{Cu}$ and hydrogen (10). The same reaction mechanism during cycling of $\mathrm{Mg}-\mathrm{Cu}-\mathrm{H}$ system was reported by other groups $[1,29]$ :

$$
\begin{aligned}
& \mathrm{Mg}_{2} \mathrm{Cu}+\mathrm{H}_{2} \longrightarrow \mathrm{MgH}_{2}+\mathrm{MgCu}_{2} \\
& \mathrm{MgH}_{2}+\mathrm{MgCu}_{2} \longrightarrow \mathrm{Mg}_{2} \mathrm{Cu}+\mathrm{H}_{2}
\end{aligned}
$$

Figure 6 presents the DSC curve started from low temperature $\mathrm{Mg}_{2} \mathrm{NiH}_{4}$ phase in $2 \mathrm{MPa}$ hydrogen, which is obtained from $2 \mathrm{Mg}+\mathrm{Ni}$ nanoparticle mixture by DSC methods in $4 \mathrm{MPa}$ hydrogen for one heating and cooling cycle. The upper dash line shows the temperature program. The middle solid line indicates the pressure change with time. During each heating and cooling cycle with different scan rates $(5,10$, and $20 \mathrm{~K} / \mathrm{min}$ ), there are two large peaks and two small ones. These peaks have the same attribution with the ones in the second and third cycles of the DSC curve in Figure 4. They are also ascribed to (5), (6), (4), and (5) in the appearance order. From the figure, we may see that the desorption reaction of $\mathrm{Mg}_{2} \mathrm{NiH}_{4}$ to form $\mathrm{Mg}_{2} \mathrm{Ni}$ (6) in $2 \mathrm{MPa}$ hydrogen shows the peak temperatures of $684.2 \mathrm{~K}$ at $5 \mathrm{~K} / \mathrm{min}, 689.2 \mathrm{~K}$ at $10 \mathrm{~K} / \mathrm{min}$, and $695.1 \mathrm{~K}$ at $20 \mathrm{~K} / \mathrm{min}$. From the pressure recording data, we obtain the real-time pressure values, which are $2.106 \mathrm{MPa}$ for $684.2 \mathrm{~K}$ at $5 \mathrm{~K} / \mathrm{min}, 2.106 \mathrm{MPa}$ for $689.2 \mathrm{~K}$ at $10 \mathrm{~K} / \mathrm{min}$, and $2.107 \mathrm{MPa}$ for $695.1 \mathrm{~K}$ at $20 \mathrm{~K} / \mathrm{min}$. These pressure, temperature and scan rate data in $2 \mathrm{MPa}$ hydrogen are described in Table 1 and the values in $4 \mathrm{MPa}$ and $1 \mathrm{MPa}$ are 
TABLE 1: Desorption temperature and pressure values from DSC measurements of $\mathrm{Mg}-\mathrm{Ni}-\mathrm{H}$ system.

\begin{tabular}{lcc}
\hline $\begin{array}{l}\text { Scan rate } \\
(\mathrm{K} / \mathrm{min})\end{array}$ & $\begin{array}{c}\text { Desorption } \\
\text { temperature }(\mathrm{K})\end{array}$ & $\begin{array}{c}\text { Desorption pressure } \\
(0.1 \mathrm{MPa})\end{array}$ \\
\hline \multirow{3}{*}{5} & 720.6 & 41.05 \\
& 684.2 & 21.06 \\
& 645.4 & 10.99 \\
\hline \multirow{2}{*}{10} & 725.8 & 41.01 \\
& 689.2 & 21.06 \\
& 652.3 & 11.05 \\
\hline \multirow{2}{*}{20} & 731.0 & 41.07 \\
& 695.1 & 21.07 \\
\end{tabular}

also included. These peaks are approximately corresponding to middle point of the desorption process. Usually we take the hydrogen equilibrium pressure of the middle point of the desorption curve during PCT measurement, and the realtime temperature of the middle point to make van't Hoff plot to obtain desorption enthalpy and entropy according to the van't Hoff equation:

$$
\ln \left(\frac{P}{P^{0}}\right)=\frac{\Delta H}{R T}-\frac{\Delta S}{R} .
$$

Using the data shown in Table 1, we could obtain the van't Hoff equations at different scan rates, which are given in Table 2. The van't Hoff equations vary with the scan rates because the peak temperatures for hydrogen desorption reaction from DSC technique differ at different scan rates. The higher the scan rate, the higher the temperature difference between peak temperature and real equilibrium temperature. If we want to obtain the van't Hoff equation at complete equilibrium state, we should take the DSC measurement at zero scan rate, which is impossible. However, in our case, the kinetics of the absorption and desorption reaction of nanostructured $\mathrm{Mg}-\mathrm{Ni}-\mathrm{H}$ system is superior. This means we can approach almost equilibrium state of the sorption reactions at low scan rates. After we measured the system at $5 \mathrm{~K} / \mathrm{min}$ rate, we made the plot. We obtain a van't Hoff equation of $\ln (P / 0.1 \mathrm{MPa})=-8123 / T+14.961$ and the formation enthalpy and entropy values of $-67.5 \mathrm{~kJ} / \mathrm{mol}$ $\mathrm{H}_{2}$ and $-124.4 \mathrm{~J} /\left(\mathrm{K} \cdot \mathrm{mol} \mathrm{H}_{2}\right)$. These results agree well with the ones from the van't Hoff equation $(\ln (P / 0.1 \mathrm{MPa})=$ $-7978 / T+15.06)$ and formation enthalpy and entropy values $\left(-66.3 \mathrm{~kJ} / \mathrm{mol} \mathrm{H}_{2}\right.$ and $-125.3 \mathrm{~J} /\left(\mathrm{K} \cdot \mathrm{mol} \mathrm{H}_{2}\right)$, resp.,) obtained by PCT technique in our previous work [23]. PCT technique is a traditional way used to make van't Hoff plot by obtaining the equilibrium pressure values of samples at various temperatures and obtain formation enthalpy and entropy values, but one whole PCT including hydrogen absorption and desorption process usually is quite time-consuming. It usually takes several days or much more depending on the hydrogen storage kinetics of the samples, measurement parameters, and equilibrium conditions. Also it has not been much noticed that the obtained equilibrium pressure values vary much with different equilibrium conditions during PCT measurements, which could contribute to some difference in the calculated van't Hoff equation and formation enthalpy and entropy results using these plateau pressure data. By DSC technique, we could make a whole van't Hoff plot in a much more time-saving way. By comparing the results from DSC method and former PCT technique, it shows DSC method is an excellent way to obtain van't Hoff equations as well as formation enthalpy and entropy values of nanostructured hydrogen storage systems, which are with good kinetics. After we reported our method [30], Rongeat et al. reported their results about thermodynamic properties of hydrides determined by high pressure DSC method in a much different way [31]. We take the middle point of the DSC reaction peak and assume that the thermodynamics values obtained by our method are not equilibrium state while with kinetics factor, so we can compare with other people's results from desorption PCT measurements. Rongeat et al. tried to give a range of thermodynamics values of the equilibrium state between absorption measurements and desorption ones. Table 3 shows the temperature values of transformation reaction between high temperature $\mathrm{Mg}_{2} \mathrm{NiH}_{4}$ phase and low temperature one, in different hydrogen pressure values and at different scan rates. From this table, we can see that the transformation temperature from LT phase to HT phase and the one from HT phase to LT phase do not change much with the different hydrogen pressure.

\section{Conclusions}

The main conclusions of this work are as follows:

(1) Nanostructured $\mathrm{Mg}-\mathrm{Ni}-\mathrm{H}, \mathrm{Mg}-\mathrm{Cu}-\mathrm{H}$ hydride systems and $\mathrm{Mg}_{2} \mathrm{Ni}, \mathrm{Mg}_{2} \mathrm{Cu}$ alloys can be obtained from $\mathrm{Mg}, \mathrm{Ni}$, and $\mathrm{Cu}$ nanoparticles by high hydrogen pressure DSC method.

(2) The preparation process and hydrogen absorption and desorption properties of nanostructured $\mathrm{Mg}$ $\mathrm{H}, \mathrm{Mg}-\mathrm{Ni}-\mathrm{H}$, and $\mathrm{Mg}-\mathrm{Cu}-\mathrm{H}$ systems were studied by DSC method. With $\mathrm{Ni}$ or $\mathrm{Cu}$ as catalyst, $\mathrm{Mg}$ nanoparticles absorb hydrogen at temperatures about 230-250 K lowered. Nanostructured Mg-H, Mg-Ni$\mathrm{H}$, and $\mathrm{Mg}-\mathrm{Cu}-\mathrm{H}$ systems show excellent hydrogen storage properties.

(3) From the temperature and hydrogen pressure values obtained in DSC measurements of nanostructured $\mathrm{Mg}-\mathrm{Ni}-\mathrm{H}$ system, van't Hoff equation was obtained as $\ln (P / 0.1 \mathrm{MPa})=-8123 / T+14.961$ at $5 \mathrm{~K} / \mathrm{min}$ scan rate. The formation enthalpy and entropy are $-67.5 \mathrm{~kJ} / \mathrm{mol} \mathrm{H}_{2}$ and $-124.4 \mathrm{~J} /\left(\mathrm{K} \cdot \mathrm{mol} \mathrm{H}_{2}\right)$. These results agree with those by PCT method.

\section{Acknowledgments}

The authors acknowledge support from the International Institute for Carbon-Neutral Energy Research (WPII2CNER), established by the World Premier International Research Center Initiative (WPI), MEXT, Japan. This work was also supported in part by JSPS KAKENHI (23860034) 
TABLE 2: Van't Hoff equations of $\mathrm{Mg}_{2} \mathrm{NiH}_{4}$ at different DSC scan rates.

\begin{tabular}{lccc}
\hline Scan rate $(\mathrm{K} / \mathrm{min})$ & Van’t Hoff equation & Formation enthalpy $\left(-\mathrm{kJ} / \mathrm{mol} \mathrm{H}_{2}\right)$ & Formation entropy $-\mathrm{J} /\left(\mathrm{K} \cdot \mathrm{mol} \mathrm{H}{ }_{2}\right)$ \\
\hline 5 & $\ln (P / 0.1 \mathrm{MPa})=-8123 / T+14.961$ & 67.5 & 124.4 \\
10 & $\ln (P / 0.1 \mathrm{MPa})=-8431 / T+15.313$ & 70.1 & 127.3 \\
20 & $\ln (P / 0.1 \mathrm{MPa})=-8793 / T+15.728$ & 73.1 & 130.8 \\
\hline
\end{tabular}

TABLE 3: Transformation temperatures between high temperature $\mathrm{Mg}_{2} \mathrm{NiH}_{4}$ phase and low temperature one in different hydrogen pressure values and scan rate conditions.

\begin{tabular}{|c|c|c|c|c|c|}
\hline \multicolumn{3}{|c|}{ LT phase to HT phase } & \multicolumn{3}{|c|}{ HT phase to LT phase } \\
\hline $\begin{array}{l}\text { Pressure } \\
(\mathrm{MPa})\end{array}$ & $\begin{array}{l}\text { Scan rate } \\
(\mathrm{K} / \mathrm{min})\end{array}$ & $\begin{array}{c}\text { Temperature } \\
(\mathrm{K})\end{array}$ & $\begin{array}{c}\text { Pressure } \\
(\mathrm{MPa})\end{array}$ & $\begin{array}{l}\text { Scan rate } \\
(\mathrm{K} / \mathrm{min})\end{array}$ & $\begin{array}{c}\text { Temperature } \\
(\mathrm{K})\end{array}$ \\
\hline \multirow{3}{*}{4} & 20 & 516.6 & \multirow{3}{*}{4} & 20 & 504.7 \\
\hline & 10 & 515.3 & & 10 & 506.2 \\
\hline & 5 & 515.0 & & 5 & 507.2 \\
\hline \multirow{3}{*}{2} & 20 & 516.5 & \multirow{3}{*}{2} & 20 & 503.9 \\
\hline & 10 & 515.6 & & 10 & 505.0 \\
\hline & 5 & 515.5 & & 5 & 506.0 \\
\hline \multirow{3}{*}{1} & 20 & 516.5 & \multirow{3}{*}{1} & 20 & 504.1 \\
\hline & 10 & 515.7 & & 10 & 504.8 \\
\hline & 5 & 515.6 & & 5 & 505.4 \\
\hline
\end{tabular}

in Japan and MOST of China (no. 2010CB631301 and 2011AA03A408).

\section{References}

[1] J. J. Reilly and R. H. Wiswall, "The reaction of hydrogen with alloys of magnesium and copper," Inorganic Chemistry, vol. 6, no. 12, pp. 2220-2223, 1967.

[2] J. J. Reilly and R. H. Wiswall, "The reaction of hydrogen with alloys of magnesium and nickel and the formation of $\mathrm{Mg}_{2} \mathrm{NiH}_{4}$ "' Inorganic Chemistry, vol. 7, no. 11, pp. 2254-2256, 1968.

[3] H. Shao, G. Xin, J. Zheng, X. Li, and E. Akiba, "Nanotechnology in Mg-based materials for hydrogen storage," Nano Energy, vol. 1, pp. 590-601, 2012.

[4] B. Sakintuna, F. Lamari-Darkrim, and M. Hirscher, "Metal hydride materials for solid hydrogen storage: a review," International Journal of Hydrogen Energy, vol. 32, no. 9, pp. 1121-1140, 2007.

[5] J. Yang, A. Sudik, C. Wolverton, and D. J. Siegel, "High capacity hydrogen storage materials: attributes for automotive applications and techniques for materials discovery," Chemical Society Reviews, vol. 39, no. 2, pp. 656-675, 2010.

[6] B. Bogdanović, T. H. Hartwig, and B. Spliethoff, “The development, testing and optimization of energy storage materials based on the $\mathrm{MgH}_{2} \mathrm{Mg}$ system," International Journal of Hydrogen Energy, vol. 18, no. 7, pp. 575-589, 1993.

[7] F. H. Froes, C. Suryanarayana, K. Russell, and C. G. Li, "Synthesis of intermetallics by mechanical alloying," Materials Science and Engineering A, vol. 192-193, no. 2, pp. 612-623, 1995.

[8] Y. Q. Lei, Y. M. Wu, Q. M. Yang, J. Wu, and Q. D. Wang, "Electrochemical-behavior of some mechanically alloyed MgNi-based amorphous hydrogen storage alloys," Zeitschrift Fur Physikalische Chemie, vol. 183, pp. 379-384, 1994.

[9] M. Y. Song, "Effects of mechanical alloying on the hydrogen storage characteristics of Mg-Xwt-Percent $\mathrm{Ni}(\mathrm{X}=0,5,10,25$ and
55) mixtures," International Journal of Hydrogen Energy, vol. 20, no. 3, pp. 221-227, 1995.

[10] G. Liang, S. Boily, J. Huot, A. Van Neste, and R. Schulz, "Hydrogen absorption properties of a mechanically milled Mg$50 \mathrm{wt} \% \mathrm{LaNi}_{5}$ composite," Journal of Alloys and Compounds, vol. 268, no. 1-2, pp. 302-307, 1998.

[11] S. Orimo and H. Fujii, "Hydriding properties of the $\mathrm{Mg}_{2} \mathrm{Ni}-\mathrm{H}$ system synthesized by reactive mechanical grinding," Journal of Alloys and Compounds, vol. 232, no. 1-2, pp. L16-L19, 1996.

[12] E. Akiba, "Hydrogen-absorbing alloys," Current Opinion in Solid State and Materials Science, vol. 4, no. 3, pp. 267-272, 1999.

[13] H. Imamura, I. Kitazawa, Y. Tanabe, and Y. Sakata, "Hydrogen storage in carbon/Mg nanocomposites synthesized by ball milling," International Journal of Hydrogen Energy, vol. 32, no. 13, pp. 2408-2411, 2007.

[14] K. Asano, H. Enoki, and E. Akiba, "Effect of Li addition on synthesis of Mg-Ti BCC Alloys by means of ball milling," Materials Transactions, vol. 48, no. 2, pp. 121-126, 2007.

[15] H. Shao, K. Asano, H. Enoki, and E. Akiba, "Correlation study between hydrogen absorption property and lattice structure of Mg-based BCC alloys," International Journal of Hydrogen Energy, vol. 34, no. 5, pp. 2312-2318, 2009.

[16] H. Shao, K. Asano, H. Enoki, and E. Akiba, "Fabrication, hydrogen storage properties and mechanistic study of nanostructured $\mathrm{Mg}_{50} \mathrm{Co}_{50}$ body-centered cubic alloy," Scripta Materialia, vol. 60, no. 9, pp. 818-821, 2009.

[17] H. Shao, K. Asano, H. Enoki, and E. Akiba, "Preparation and hydrogen storage properties of nanostructured $\mathrm{Mg}-\mathrm{Ni} \mathrm{BCC}$ alloys," Journal of Alloys and Compounds, vol. 477, no. 1-2, pp. 301-306, 2009.

[18] H. Shao, K. Asano, H. Enoki, and E. Akiba, "Fabrication and hydrogen storage property study of nanostructured $\mathrm{Mg}-\mathrm{Ni}-\mathrm{B}$ ternary alloys," Journal of Alloys and Compounds, vol. 479, no. 1-2, pp. 409-413, 2009. 
[19] K. Yamamoto, S. Tanioka, Y. Tsushio et al., "Influence of elemental diffusion on low temperature formation of $\mathrm{MgH}_{2}$ in TiMn1.3T0.2Mg (T equals 3d-transition elements)," Journal of Alloys and Compounds, vol. 243, no. 1-2, pp. 144-150, 1996.

[20] J. Lu, J. C. Young, Z. F. Zhigang, Y. S. Hong, and E. Rönnebro, "Hydrogen storage properties of nanosized $\mathrm{MgH}_{2}-0.1 \mathrm{TiH}_{2}$ prepared by ultrahigh-energy-high-pressure milling," Journal of the American Chemical Society, vol. 131, no. 43, pp. 15843-15852, 2009.

[21] H. Shao, T. Liu, X. Li, and L. Zhang, "Preparation of $\mathrm{Mg}_{2} \mathrm{Ni}$ intermetallic compound from nanoparticles," Scripta Materialia, vol. 49, no. 6, pp. 595-599, 2003.

[22] H. Shao, T. Liu, and X. Li, "Preparation of the $\mathrm{Mg}_{2} \mathrm{Ni}$ compound from ultrafine particles and its hydrogen storage properties," Nanotechnology, vol. 14, no. 3, pp. L1-L3, 2003.

[23] H. Shao, H. Xu, Y. Wang, and X. Li, "Preparation and hydrogen storage properties of $\mathrm{Mg}_{2} \mathrm{Ni}$ intermetallic nanoparticles," Nanotechnology, vol. 15, no. 3, pp. 269-274, 2004.

[24] H. Shao, T. Liu, Y. Wang, H. Xu, and X. Li, "Preparation of Mgbased hydrogen storage materials from metal nanoparticles," Journal of Alloys and Compounds, vol. 465, no. 1-2, pp. 527-533, 2008.

[25] J. Zou, X. Zeng, Y. Ying et al., "Study on the hydrogen storage properties of core-shell structured $\mathrm{Mg}-\mathrm{RE}(\mathrm{RE}=\mathrm{Nd}, \mathrm{Gd}$, Er) nano-composites synthesized through arc plasma method," International Journal of Hydrogen Energy, vol. 38, pp. 23372346, 2013.

[26] J. X. Zou, X. Q. Zeng, Y. J. Ying, P. Stephane, and W. J. Ding, "Preparation and hydrogen sorption properties of a nano-structured $\mathrm{Mg}$ based $\mathrm{Mg}$-La-O composite," International Journal of Hydrogen Energy, vol. 37, pp. 13067-13073, 2012.

[27] H. Shao, H. Xu, Y. Wang, and X. Li, "Synthesis and hydrogen storage behavior of $\mathrm{Mg}$-Co-H system at nanometer scale," Journal of Solid State Chemistry, vol. 177, no. 10, pp. 3626-3632, 2004.

[28] H. Shao, Y. Wang, H. Xu, and X. Li, "Preparation and hydrogen storage properties of nanostructured $\mathrm{Mg}_{2} \mathrm{Cu}$ alloy," Journal of Solid State Chemistry, vol. 178, no. 7, pp. 2211-2217, 2005.

[29] F. K. Hsu, C. W. Hsu, J. K. Chang, C. K. Lin, S. L. Lee, and C. E. Jiang, "Structure and hydrogen storage properties of $\mathrm{Mg}_{2} \mathrm{Cu} 1-$ $\mathrm{xNix}(\mathrm{x}=0-1)$ alloys," International Journal of Hydrogen Energy, vol. 35, no. 24, pp. 13247-13254, 2010.

[30] H. Shao, Preparation and hydrogen storage properties of $\mathrm{Mg}$ based nanostructures materials [Ph.D. thesis], Beijing Unvieristy, 2005.

[31] C. Rongeat, I. Llamas-Jansa, S. Doppiu et al., "Determination of the heat of hydride formation/decomposition by HighPressure Differential Scanning Calorimetry (HP-DSC)," Journal of Physical Chemistry B, vol. 111, no. 46, pp. 13301-13306, 2007. 

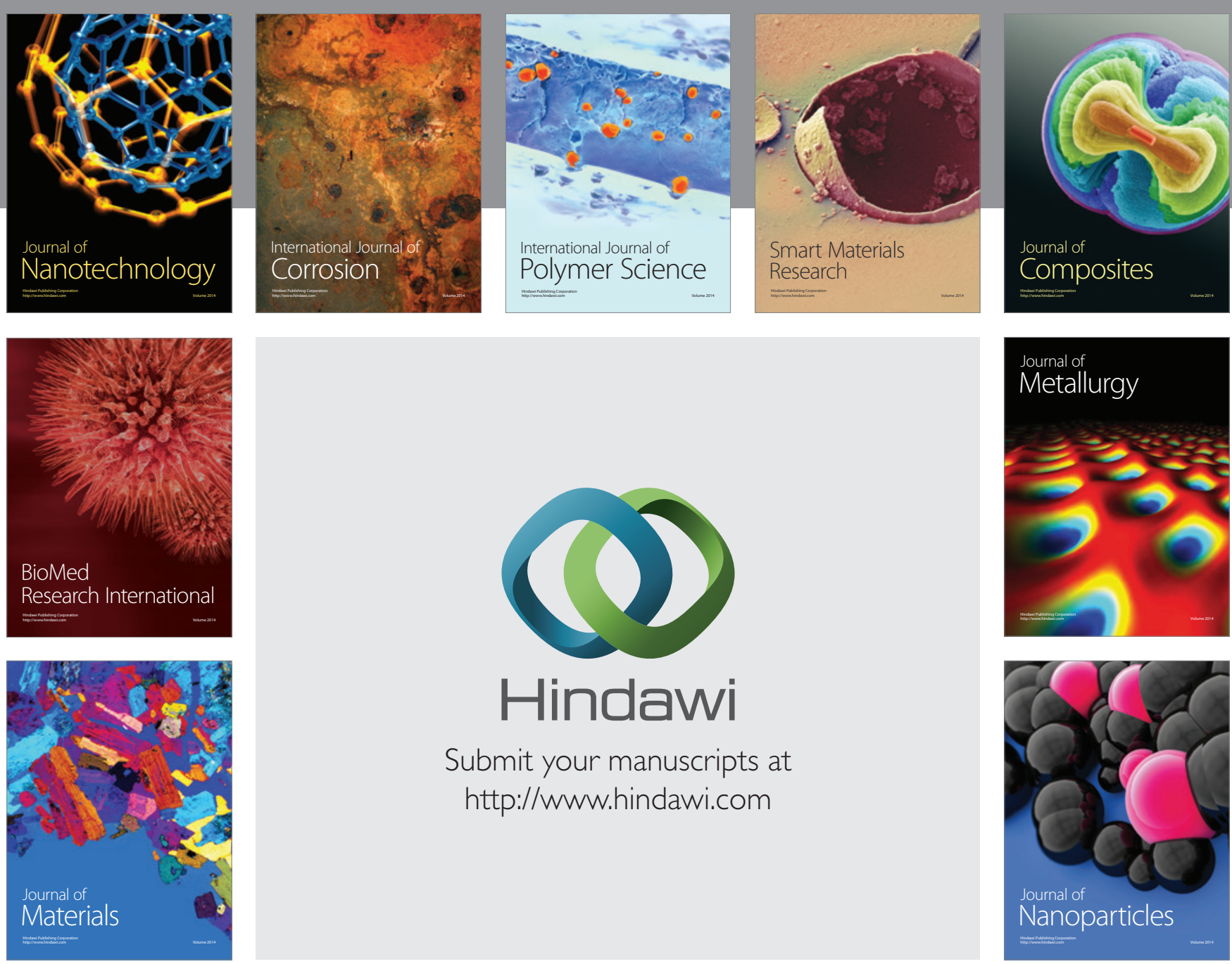

Submit your manuscripts at http://www.hindawi.com
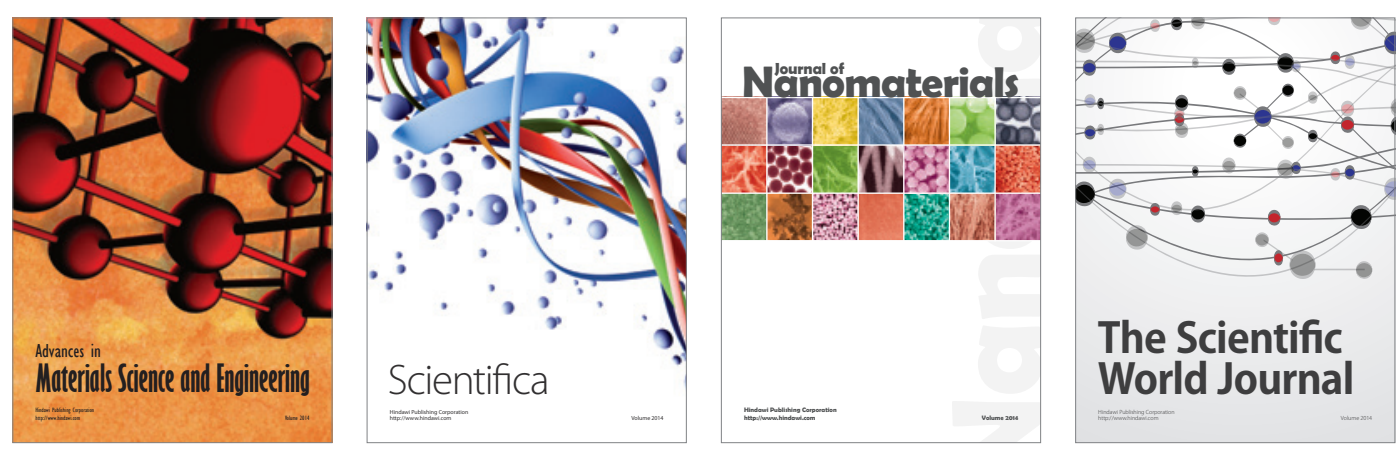

\section{The Scientific World Journal}
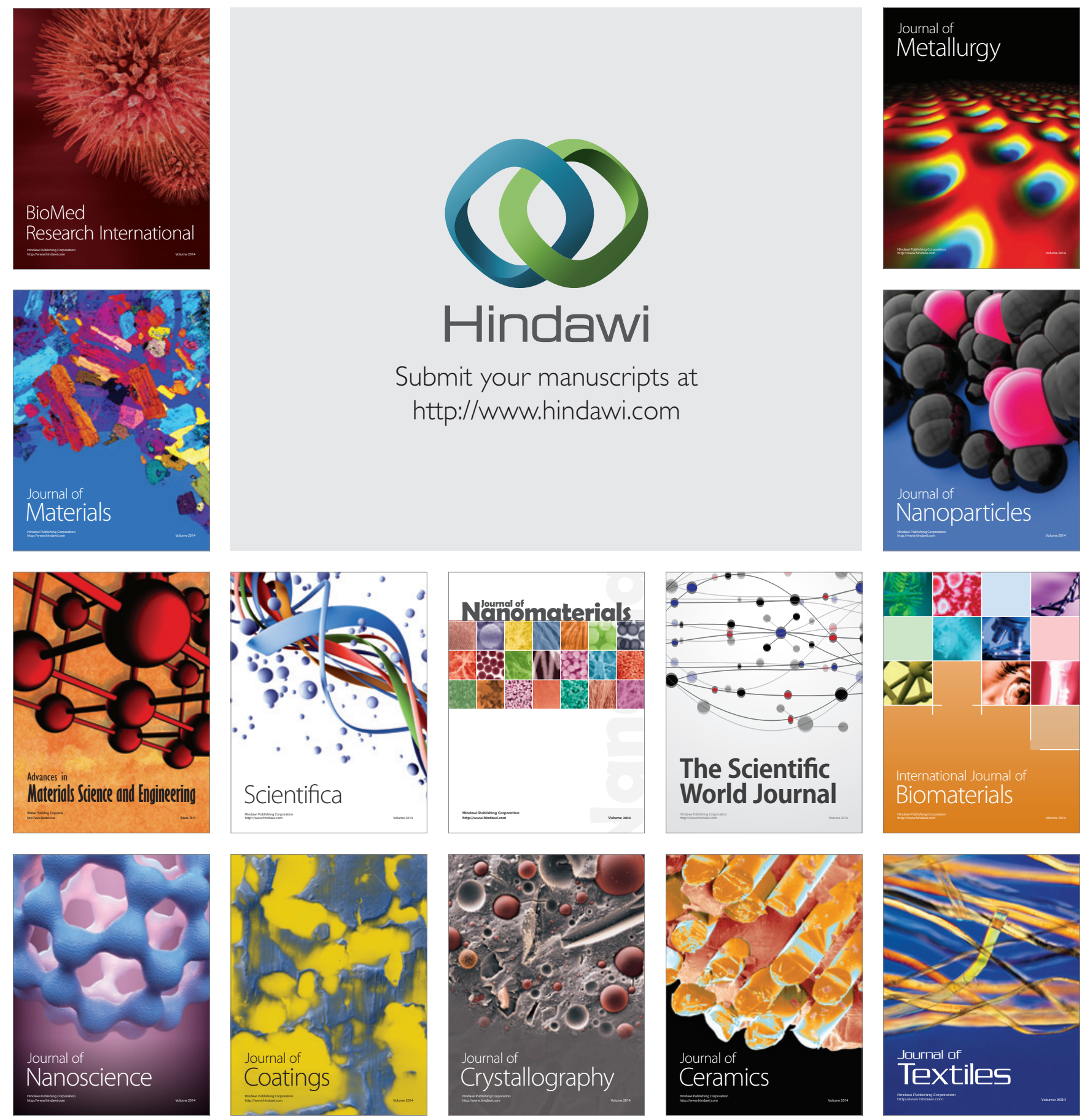